Available online at

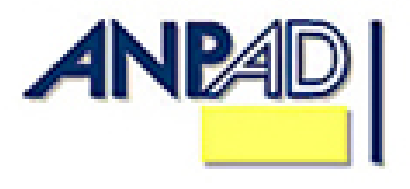
http://www.anpad.org.br/bar

BAR, Curitiba, v. 8, n. 2, art. 1, pp. 107-132, Apr./June 2011

$(\mathrm{coc}) \mathrm{EY}-\mathrm{N}$

\title{
Determinants of Export Performance: a Study of Large Brazilian Manufacturing Firms
}

Jorge Carneiro *

E-mail address: jorgemtc@ @iag.puc-rio.br Pontifícia Universidade Católica do Rio de Janeiro - IAG/PUC-RJ Rio de Janeiro, RJ, Brazil.

Angela da Rocha

E-mail address: angelarocha@iag.puc-rio.br Pontifícia Universidade Católica do Rio de Janeiro - IAG/PUC-RJ Rio de Janeiro, RJ, Brazil.

Jorge Ferreira da Silva E-mail address: shopshop@iag.puc-rio.br Pontifícia Universidade Católica do Rio de Janeiro - IAG/PUC-RJ

Rio de Janeiro, RJ, Brazil.

* Corresponding author: Jorge Carneiro

Rua Dezenove de Fevereiro, 127 / 201, Botafogo, Rio de Janeiro, RJ, 22280-030, Brazil.

Copyright (C) 2011 Brazilian Administration Review. All rights reserved, including rights for translation. Parts of this work may be quoted without prior knowledge on the condition that the source is identified. 


\begin{abstract}
This research investigated the impact the external environment, firm characteristics and firm strategy have on export performance. To this end, a survey was administered to 448 large Brazilian exporters of manufactured products. A structural equation modeling (SEM) approach was used to fit the conceptual model to empirical data. An extensive set of procedures for the validation of measurement models was used. Export performance exhibited a multidimensional structure and the model explained $76.6 \%$ and $40.1 \%$ of the observed variance of past export revenues and of past export profitability, respectively.
\end{abstract}

Key words: export performance; international business; Brazil. 


\section{Introduction}

Research on export performance has discovered several influencing variables, but the type and magnitude of the impacts have not been determined (Chetty \& Hamilton, 1993; Theodosiou \& Leonidou, 2003). The picture gets more complex when considering that the impact of a given factor may depend on the specific measure of performance used, but none of the existing measures has reached universal acceptance. Moreover, there are probably many simultaneous relationships and feedback effects, not only between influencing factors and export performance but also among the influencing factors themselves.

This paper aimed at presenting and testing an integrative model of the influence of variables of the external environment, firm characteristics and firm strategy on the export performance of large Brazilian manufacturers.

After this brief introduction, a review of the literature on the determinants of export performance is presented. Next the conceptualization and operationalization of the focal construct are addressed, followed by the conceptual model and hypotheses used for this study. Methods and data, as well as respective measures of the constructs of the study, are then exhibited. Results are then presented and discussed, with some conclusions given to close the paper.

\section{Literature Review on the Determinants of Export Performance}

In the Strategic Management literature, authors have identified several factors influencing organizational performance. There are variables related to the external environment, such as industry structure (Porter, 1980) and type of industry (Hawawini, Subramanian, \& Verdin, 2003; McGahan \& Porter, 1997). Internal firm characteristics, such as risk aversion and tolerance for ambiguity (Gupta \& Govindarajan, 1982), organizational culture, access to scarce resources, managerial competence, and luck (Jacobson, 1990), degree of business unit autonomy and marketing orientation (Slater \& Narver, 1993) are also important. Variables related to firm strategy have also been shown to influence performance, such as competitive strategy (Hill \& Deeds, 1996; Porter, 1985), strategic posture (Slater \& Narver, 1993), or strategic planning process (Pearce, Robbins, \& Robinson, 1987). A contingent perspective has also been suggested, whereby the influence of a given variable would not be universal, but rather depend on the level of another intervening variable (D. Miller, 1988; Powell, 1992; Snow \& Hrebiniak, 1980; Venkatraman \& Prescott, 1990; White, 1986).

In International Business studies, several literature reviews indicated the most frequently cited variables used to explain export performance. Aaby and Slater (1989) grouped them into four sets: firm characteristics (size, managerial commitment, managerial perceptions), firm competences (technology, market knowledge, market planning, export policy, control systems, quality control, communication skills), export strategy (market selection, use of intermediates, product mix, product development, promotion, pricing), and external environment. Zou and Stan (1998) considered them either internal (export strategy, managers' perceptions and attitudes, managers' characteristics, and firm's characteristics and competences), or external (industry characteristics, external and domestic market characteristics) determinants of export performance. Moini (1995) suggested three broad classes: organizational characteristics (size, international experience, competitive advantages, etc.); managers' expectations (both positive and negative); and managers' characteristics (age, formal education, experience, knowledge of foreign languages); while adding a fourth factor, systematic search for new external markets. Katsikeas, Leonidou and Morgan (2000) review led to two sets of factors - target market selection and export strategy - with direct effect on export performance and three sets of factors - managers' characteristics, organizational characteristics and environmental variables - indirectly influencing export performance. Leonidou, Katsikeas and Samiee (2002) found that the impact on export performance varied according to the specific facet or measure of export 
performance selected, and that five types of variables seemed to dominate most of the studies: managers' characteristics, organizational factors, environmental forces, export target, and export marketing strategy.

Holzmüller and Stöttinger (1996) argued that the vast majority of empirical research on export performance ignored the role of intervening variables. They suggested that partial models were used when more complex models were needed. They proposed that export performance would receive direct and indirect influences from organizational culture, subjective managers' characteristics, objective managers' characteristics, objective firm's characteristics and the external environment.

In general, the literature review indicates several factors influencing export performance related to the external environment, organizational and managerial characteristics, the specific export strategy adopted and the planning of each export venture.

\section{Conceptualization and Operationalization of Export Performance}

Export performance is thus a complex and multifaceted construct (Cavusgil \& Zou, 1994; Matthyssens \& Pauwels, 1996; Shoham, 1998, 1999). The success of a firm, division, or export venture cannot usually be communicated with a single metric; instead, several perspectives may have to be considered. Moreover, since performance objectives may be incompatible with one another, and improving on one dimension may come at the expense of another, success may be a matter of degree instead of just a yes or no question.

Traditional economic measures may indicate whether a company has performed well in the recent past, but are no guarantee for continuing success (Barney, 1996). As for market measures, an increase in market share might express such distinct facts as greater acceptance of a product, buying market share by cutting off prices, or investing heavily in promotions. The metric itself however does not tell whether a company's revenues and profits increased more or less than its competitors' or whether performance, defined in broader terms, actually improved. Furthermore, when a firm is starting or entering a new market, it may accept short-term financial losses as it gains experiential knowledge or develops brand awareness, which may later be important drivers of performance.

Researchers (e.g., Conant, Mokwa, \& Varadarajan, 1990; Matthyssens \& Pauwels, 1996) have advocated the use of multiple dimensions to conceptualise performance. Venkatraman and Ramanujam (1986) analysed the advantages and disadvantages of financial vs. operational indicators as well as primary $v s$. secondary data sources. Hirschey and Wichern (1984) suggested that accounting measures do not reflect the same underlying profitability phenomenon as captured by market measures. Fiegenbaum, Hart and Schendel (1996) proposed the use of several reference points: internal (strategic inputs and outputs) vs. external (competitors, customers, other stakeholders) as well as past $v s$. future.

Past data on a given time period may be useful for analysis and comparisons but they are only a picture of a moment in time and say little about the firm's history and past progress, or its future performance. Present-value measures (Barney, 1996) incorporate expected future performance prospects, measured at the present time, and may be appropriate to analyze long-term results especially when a company is taking strategic actions that may be detrimental to short-term performance. Dynamic measures that capture change in performance indicators along time can be important to understand how well a company has been progressing in the pursuit of its objectives and may serve as a better predictor of future performance. However, although dynamic measures may help verify progress, they may not be universally applicable. For example, in the first steps of a new activity, the previous base against which to compare results may be too small to be meaningful (Calof, 1993). Also, when a company has attained a given market position, further growth may be difficult. In such cases, market growth might not be an appropriate metric. But, since future performance might be 
influenced by past performance (Bijmolt \& Zwart, 1994; March \& Sutton, 1997) longitudinal performance indicators might be appropriate to capture such influence.

Because "an individual export venture is successful if the targets set are met or exceeded" (Madsen, 1998, p. 82), and can only be judged by those who set the targets, the use of both objective and subjective measures has been suggested, as well as the use of relative measures (against some external or internal reference). Katsikeas et al. (2000) identified three performance perspectives in the literature (effectiveness, efficiency, and adaptiveness); four frames of reference: domestic (export performance compared with domestic performance), industry (comparison against competitors), goal (whether or not pre-defined goals have been attained), and temporal (evolution over time); three different viewpoints: internally oriented, competitor-centered and customer-focused; and three temporal orientations: historical, current, and future performance. Matthyssens and Pauwels (1996) also proposed a multidimensional approach to export performance, comprising five dimensions: level of analysis, frame of reference, temporal orientation, types of measures, and data collection method.

In the particular case of the performance construct, since many dimensions and indicators are relevant to measure success (or failure thereof), it may be wise to have an indicator that consolidates several aspects of the construct. For example, overall firm performance vis-à-vis competitors or attainment of objectives, or perceived success, or satisfaction with the results as a whole are indicators that seem to capture a larger picture, and simultaneously incorporate several important aspects, other than just those covered by economic or market indicators alone. Such aggregated metrics explicitly or implicitly weigh and consolidate other indicators.

Since performance is better measured by multiple indicators, the relationship of the indicators to the underlying export performance construct has to be examined. In a reflective measurement perspective, the observed items are considered or assumed to be effects of an underlying latent construct, whereas in a formative measurement perspective, the items are assumed to cause, or determine a latent construct (Bollen \& Lennox, 1991; Diamantopoulos, 1999; Diamantopoulos \& Winklhofer, 2001).

Drawing on an extensive review of the theoretical, empirical, meta-analytical and methodological literature, this research uncovered several aspects by which the construct could be conceptualized (Table 1) and operationalized (Table 2). This framework builds heavily on other works (especially Katsikeas, Leonidou, \& Morgan, 2000, and Matthyssens \& Pauwels, 1996), adding to them in terms of breadth of coverage and internal homogeneity of its categories.

Table 1

Generic Framework for the Characterization of Export Performance - Conceptual Aspects

\begin{tabular}{llll}
\hline \multicolumn{4}{c}{ Conceptual Aspects } \\
\hline Stakeholders' viewpoint & \multicolumn{1}{c}{ Class of measures } & Frame of reference & Temporal orientation \\
\hline - Stockholders & - Economic & - Absolute & $\cdot$ Static \\
- Clients & - Market & $\cdot$ Relative & $\cdot$ recent past \\
- Employees & - Internal business & $\cdot$ main competitors' & $\cdot$ future expectations \\
- Managers & processes & average & $\cdot$ Dynamic \\
- Debt holders & - Innovation and learning & $\cdot$ benchmark & $\cdot$ change in recent past \\
- Suppliers & - Strategic & $\cdot$ domestic operations & $\cdot$ expected change for the \\
- Channels & - Social & $\cdot$ other international & future \\
- Business partners & - Environmental & operations in the firm & \\
- Local community & - Behavioral / Situational & $\cdot$ pre-set goals & \\
- Governments & - Overall & & \\
\hline
\end{tabular}

Note. Source: adapted and enlarged from Matthyssens and Pauwels (1996) and Katsikeas et al. (2000). 
Table 2

\section{Generic Framework for the Characterization of Export Performance - Methodological} Decisions

\begin{tabular}{lll}
\hline \multicolumn{1}{c}{ Unit of analysis } & \multicolumn{1}{c}{ Methodological Decisions } & \\
\hline \multicolumn{1}{c}{ Country / region } & \multicolumn{1}{c}{ Mode of assessment } & \multicolumn{1}{c}{ Operational representation } \\
- Industry & Objective & $\cdot$ Observed variable(s) only \\
- Whole firm & $\cdot$ from secondary sources & $\cdot$ single \\
- Division / SBU & $\cdot$ self-reported & $\cdot$ multiple \\
- All export operations of the firm & $\cdot$ Subjective (from primary sources) & $\cdot$ Latent variable(s) \\
- Specific product-country & $\cdot$ self-evaluation & $\cdot$ single vs. multiple latent \\
combination (export venture) & $\cdot$ evaluation by competitors & variables \\
- Specific product-client-country & $\cdot$ evaluation by external experts & $\cdot$ single- vs. higher-order \\
combination & $\cdot$ Subjective (from secondary & arrangement \\
& sources) & $\cdot$ reflective vs. formative \\
& $\cdot$ Case material & perspective
\end{tabular}

Note. Source: adapted and enlarged from Matthyssens and Pauwels (1996) and Katsikeas et al. (2000).

While Tables 1 and 2 present general aspects that cover the content domain and the methodological particularities of the conceptualization and operationalization of the performance construct, we contend that practical limitations usually impose constraints on the number of variables that can be collected and used to estimate statistical models. So, any empirical study would have to select some particular sub-set of dimensions and measures (as will be discussed in the Measures section ahead and also presented in Figure 3).

\section{Conceptual Model and Hypotheses}

Given the multiplicity of factors that can account for performance differences, it has been suggested that researchers should build reasonably balanced conceptual models incorporating variables from several conceptual groups (e.g. Schendel, 1997). Such caution should decrease the chance of inadvertently overemphasizing the effect of a given variable when, in fact, such effect might be shared with other variables left out of the model.

\section{Conceptual Model}

Ideally the conceptual model ought to have several desirable properties. First of all, in order to avoid specification errors, several explanatory variables that bear influence on the dependent variables should be included. Second, in order to improve validity of the constructs, several dimensions should be considered for each latent variable, especially when they are deemed to be multifaceted. Third, in order to improve reliability, several indicators should be used for each dimension. On the other hand, there are practical constraints. For example, it may not be feasible to collect such a large sample as would be necessary for so many indicators to satisfy statistical requirements. Also, more indicators would lead to a longer questionnaire, eventually increasing non-response rates or response bias, and jeopardizing validity.

Our expectation prior to fieldwork was to receive around 400 valid responses. Considering an ideal minimum of three indicators per latent variable (Hair, Black, Babin, \& Anderson, 2005; Rindskopf \& Rose, 1988) and that sample size, N, should be higher than the number of variances plus covariances among the indicators, that is, $\mathrm{N}>\mathrm{n} *(\mathrm{n}+1) / 2(\mathrm{n}=$ number of indicators $)$, this would 
impose a limit of nine latent variables, including endogenous and exogenous constructs. Supposing that we would operationalize the export performance construct by two or three dimensions (latent variables), this would leave room for six or seven explanatory factors, each to be represented by one single dimension.

However, we could not be sure whether our operationalization for each latent variable would show the desirable psychometric properties when empirically tested. So, we chose initially to build a conceptual model with 12 exogenous constructs, which would represent the three major areas of influence in a balanced manner (Figure 1).


Figure 1. Exogenous Constructs Chosen for the Preliminary Explanatory Model

Note. Exogenous constructs kept in the final explanatory model are shown in bold-face type.

While there is a myriad of variables that have been argued to influence export performance, the researcher has to deal with the challenge of building a reasonably parsimonious model that nonetheless contemplates a satisfactory coverage of the determinants (in order to not inadvertently overestimate the influence of any particular determinant). Following the literature, we initially selected four determinants related to the external environment: development level of the target country (Aulakh, Kotabe, \& Teegen, 2000; Christensen, Rocha, \& Gertner, 1987), psychic distance and business distance (Evans \& Mavondo, 2002; O'Grady \& Lane, 1996), comparative advantages (Itaki, 1991; Porter, 1990), and barriers in the host country (Madsen, 1989). Another four determinants related to the firm were also initially included: firm size (Katsikeas, Piercy, \& Ioannidis, 1996; Reid, 1981); degree of internationalization (Kogut, 1985; Porter, 1990), managers' propensity for risk (Axinn, 1988; Gomez-Mejia, 1988), and status of the exporting activity (Axinn, Noordewier, \& Sinkula, 1996; Das, 1994). Also, four determinants related to strategy were considered: systematization of export planning (Bijmolt \& Zwart, 1994; Shoham, 1996), degree of differentiation of the export venture's offer (Knight, Madsen, \& Servais, 2004; Madsen, 1989), degree of adaptation of product mix (Cavusgil \& Zou, 1994; Shoham, 1999), and price competiveness (Cavusgil \& Zou, 1994; Das, 1994; Madsen, 1989).

After the validation tests, five influencing factors, which showed higher degrees of construct validity, were kept in the final explanatory model. Three of them are related to the external environment - development level of host country, psychic distance, and business distance; one is related to firm characteristics - status of the exporting activity; and one is related to strategy systematization of export planning. Although the three major areas of influence appear in the final model, their representation is not as well balanced as desirable, but it was a necessary trade-off between model specification requirements and model validity.

In this study we were interested in investigating economic outcomes of the export activities. Conceptual reasoning led us to initially represent export performance as a three-dimensional construct: export venture's revenues, growth in export venture's revenues, and export venture's profitability. 
While revenues indicate the magnitude of exports, profitability expresses the results in terms of efficiency (that is, outcomes vs. efforts to reach them); both revenues and profitability signal a static perspective, while growth (in revenues) reveals a dynamic view of the results. The representation of the construct with these three dimensions offers a satisfactory coverage of economic aspects of the conceptual domain depicted in Table 1.

\section{Hypotheses of the study}

Research hypotheses about the influence of each of the twelve preliminary explanatory factors over the three dimensions of export performance were initially raised. As we purified the measurement model and reached a more simple final model, eight hypotheses were tested.

Psychic distance. The concept of psychic distance is an important explanatory variable in the Uppsala internationalization model (Johanson \& Vahlne, 1977). Preference for psychically close (similar) countries and gradual expansion to more psychically distant (different) countries as a firm gains experiential knowledge implicitly reflects a quest for higher economic return or lower risk, although this association between psychic distance and economic return was not explicitly stated in the model. Two hypotheses were raised:

H1a: There is a negative association between psychic distance and export performance in terms of export venture's revenues and their growth.

H1b: There is a negative association between psychic distance and export performance in terms of export venture's profitability.

Business distance. The indicators we chose to operationalize psychic distance did not empirically cluster together, leading us to consider that some of them reflected a distinct, although related concept, which we interpreted as business distance. The concept of business distance and the impact of differences in the business environment have been discussed in the literature $(e . g$. Welch \& Luostarinen, 1988). Evans and Mavondo (2002) argued that while the cultural component of psychic distance (related to Hofstede's (1997) dimensions) has received a great deal of attention in the literature, the business component has been neglected to some extent. Business distance would reflect "differences between the home and foreign market regarding the legal and political environment, economic environment, market structure, business practices and language" (p. 520). Two hypotheses were raised:

H2a: There is a negative association between business distance and export performance in terms of export venture's revenues and their growth.

H2b: There is a negative association between business distance and export performance in terms of export venture's profitability.

Barriers in the host country. Madsen (1989) reported a negative association between commercial barriers and export performance once the collinear relationship between commercial barriers and external market growth rate had been controlled. We proposed the following two hypotheses:

H3a: There is a negative association between barriers to exports in the host country and export performance in terms of export venture's revenues and their growth.

H3b: There is a negative association between barriers to exports in the host country and export performance in terms of export venture's profitability.

Status of the exporting activity. Studies reported a positive relationship between export performance and the degree of autonomy of the exporting activity (Das, 1994); export performance and export policy, including organizational structure, attitude towards exports, and export planning (Bijmolt \& Zwart, 1994); and export performance and level of priority given to exports (Axinn et al., 
1996). Madsen (1989), however, reported mixed evidence of the impact of decentralization and decision power of the export unit on export performance. Beamish, Karavis, Goerzen and Lane (1999) found that firms with an independent organizational structure dedicated to exports showed higher export revenue growth rates, although they did not find any significant difference in export revenues. However, it is reasonable to infer that, as time goes by, firms with higher export revenue growth rates will also tend to show higher revenues. We advanced the following hypothesis:

H4: There is a positive association between status of the exporting activity and export performance in terms of export venture's revenues and their growth.

Systematization of export planning. Several export planning variables have been suggested to influence export performance, such as formalization of the planning process (Madsen, 1989), systematic attention to new markets (Moini, 1995), market research intensity (Johanson \& Vahlne, 1977), use of planning instruments (Shoham, 1996), and frequency of visits to foreign markets (Cicic, Patterson, \& Shoham, 2002; Moini, 1995). Nevertheless, the relationship between planning and performance might be contingent on the level of environmental turbulence (C. Miller \& Cardinal, 1994; Shoham, 1999). Bijmolt and Zwart (1994) contended that the causal direction of the relationship might be inverted, that is, instead of a direct effect on export performance, perceived export results would influence the amount of support managers give to the activity, leading to changes in the export planning process. Walters and Samiee (1990) found, in general, support for a positive association between export planning and export performance.

In fact, the association of planning and performance has produced conflicting findings in the literature (Chetty \& Hamilton, 1993; C. Miller \& Cardinal, 1994; Pearce, Freeman, \& Robinson, 1987; Robinson \& Pearce, 1988). Although higher systematization of export planning tends to lead to higher costs, it also tends to lead to better decisions regarding the choice of countries and of market segments as well as more substantiated marketing mix decisions. The overall impact on export profitability would be expected to be positive. However, the impact on revenues is not so clear-cut. While, on the one hand, higher systematization of export planning may allow the firm to identify new opportunities abroad (consequently, higher revenues), it may, on the other hand, lead to the rejection of some projects that might have been deemed attractive if a previous scrutiny had not been conducted (consequently, lower revenues). We propose that systematization of export planning positively affects export profitability:

H5: There is a positive association between systematization of export planning and export performance in terms of export venture's profitability.

\section{Methods and Data}

\section{Population, sample and data collection procedures}

A survey was conducted with large Brazilian exporters of manufactured products, selected from a list of the 5,000 largest Brazilian exporters (firms with export revenues above US\$700,000 in 2006) provided by FUNCEX, a private nonprofit organization supported by Brazilian exporters. Foreignowned firms were excluded from the list because of potential different objectives and transfer pricing mechanisms. Service firms, exporters of commodities and trading companies were also removed. The final list included 3,057 exporters.

The unit of analysis was the export venture, as suggested by several researchers (e.g., Cavusgil \& Kirpalani, 1993; Matthyssens \& Pauwels, 1996).

In order to increase response rates, semantic-differential scales were employed ( $c f$. Matthyssens \& Pauwels, 1996; Shoham, 1998). A pre-test was run with 11 export managers, four academics and two area experts. As a result, some questions and response options were reworded while others were 
removed. Financial and time constraints allowed for telephone contact with only around $20 \%$ of the target firms, who received an e-mail with the questionnaire attached. A mailed questionnaire with a pre-paid return envelope was sent to the remaining $80 \%$ of the firms.

A sample of 448 exporters was obtained, resulting in a response rate of $15.5 \%$. No systematic non response bias - in terms of type of industry, geographic region of origin, or export revenues - was observed. Four variables and 34 cases were removed because they had more than $15 \%$ missing values. Since missing data exhibited an MCAR (missing completely at random) pattern at the 10\% significance level (Little \& Rubim, 1987), we employed a hot deck imputation procedure to estimate, by means of analogy with other cases in the sample, the missing values of those variables originally obtained from secondary sources (information about these sources is presented in the Measures section). For the other variables, we used four methods for the estimation - simple average listwise, simple average pairwise, multiple linear regression and E-M estimation. The last three methods produced fairly similar estimates; an average was then used for each variable with missing data. We also removed 25 outliers, considering the $p 1$ and $p 2$ criteria provided by $\operatorname{AMOS}^{\mathrm{TM}} 7.0$ (Arbuckle, 2006) and ratio of the Mahalanobis distance to degrees of freedom $\left(D^{2} / d f>4\right.$, cf. Hair et al., 2005). The final sample used in the analysis had 389 cases.

\section{Development of the final explanatory model}

Given the complex nature of the constructs and the fact that multiple simultaneous relationships were expected between independent and dependent constructs in the explanatory model, a structural equation modeling approach was employed. Parameters were estimated by an asymptotic distribution-free method (ADF) because variables did not follow a normal distributional pattern. SPSS $^{\mathrm{TM}} 15.0$ and $\mathrm{AMOS}^{\mathrm{TM}} 7.0$ were the statistical packages used.

For this study we assembled a comprehensive set of procedures for the assessment of the psychometric properties of variables and the validation of measurement models of complex constructs. Although none of the 35 steps of our integrated framework (Tab) is new, its full use has never been reported in any single study on export performance (nor, in fact, in any other study that we know of). The validation framework basically checks for unidimensionality (degree of distinctiveness between dimensions and between constructs), construct validity, reliability (of constructs and indicators), overall model fit and stability of model parameters.

\section{Table 3}

Integrated Framework for Assessment of the Degree of Satisfactoriness of Measurement Models of Reflectively-Measured Constructs

\section{Steps of the assessment framework}

Run an exploratory factor analysis on a calibration sample in order to check whether:

1. The factorial structure (number of distinct factors and the particular association of indicators to factors) that emerges from empirical data replicates what was expected from theoretical considerations

2. No indicator loads high $(\geq .30)$ on more than one factor

3. Each factor is represented by at least three high-loading indicators or, at least on average, there are more than three high-loading indicators per factor

4. Signs (positive or negative) of the loadings are compatible with theory and, in each factor, have the same direction (given that negatively-worded items have been properly recoded) 


\section{Table 3 (continued)}

\section{Steps of the assessment framework}

Run a confirmatory factor analyses over the competing models previously advanced (remember to use a validation sample, distinct from the one used in the exploratory analysis) in order to estimate model parameters and check for the internal consistency and the unidimensionality of the constructs, by verifying whether:

5. The parameter estimation procedure does not produce any improper or non-admissible solution

6. Signs of loadings are compatible with theoretical expectations and, in each construct, have the same direction

7. Inter-item within-construct correlations (that is, correlations between pairs of indicators associated with the same latent variable), as implied (estimated) by the measurement model, are adequately high $(\geq .20)$

8. Inter-item within-construct correlations, as implied by the model, are statistically significant

9. For each latent variable (dimension), average inter-item within-construct correlations (that is, the simple arithmetic average of all inter-item correlations of a given latent variable) is adequately high, that is, $\geq .30$

10. Each item-to-total within-construct correlation (correlation of a given indicator with the sum of the scores of all other indicators associated with the same latent variable, excluding itself) is high enough, that is, $\geq .50$

11. Item-to-total within-construct correlations are statistically significant

12. For each latent variable, average item-to-total within construct correlations are adequately high

13. Inter-item within-construct correlations are statistically higher than inter-item between-construct correlations (correlations between items associated with a given latent variable and items associated with another latent variable)

14. For each indicator, average inter-item within-construct correlation and all item-to-total within-construct correlations are not too high, that is, they are each lower than .90

15. Standardized loadings are adequately high, that is, higher than .50 and, ideally, higher than .707

16. Standardized loadings are statistically significant

17. Standardized multiple correlations (SMC) are adequately high, that is, $\geq .50$

18. Average variance extracted (AVE) of each latent variable is $\geq .50$

19. Measurement error variances (variances in the error terms of each indicator) are statistically significant

20. Between-construct error covariances (that is, covariances between error terms of items assigned to distinct dimensions) are not significant

21. An item does not show large negative standardized residuals with items in its assigned dimension

22. An item does not show large positive standardized residuals with any other item associated with a different latent variable (dimension)

23. The completely standardized expected parameter change (of each parameter estimated by the model) is reasonably small

24. Modification indices are small, that is, lower than 3.84

25. Within-construct error covariances (that is, covariances between error terms related to indicators assigned to the same latent variable) are not statistically significant

26. Correlations between (aggregated scores of) each pair of latent variables (dimensions) is statistically different from 1.0

27. Average variance extracted (AVE) for each latent variable is higher that the square of the correlation between this latent variable and any other latent variable (inter-construct correlation)

28. $\Delta-\chi^{2}$ (that is, difference in the degree of fit between two models, taking into account the difference in the degrees of freedom) between a model that restricts the correlation between two latent variables to be 1.0 and another model that allows this correlation to be freely estimated is statistically significant 


\section{Table 3 (continued)}

\section{Steps of the assessment framework}

29. $\Delta-\chi^{2}$ between a model where each dimension keeps its a priori assigned indicators and one where all indicators of any two dimensions are considered indicators of one same dimension is statistically significant

Once the degree of validity and of distinctiveness of the dimensions has been assessed, reliability should also be checked.

30. The composite reliability coefficient, $\rho_{c}$, of each latent variable is adequately high, that is, $\geq .60$

31. The reliability index of each individual indicator, $\rho_{\mathrm{i}}$, is adequately high

Besides checking the psychometric properties of indicators and latent variables, it is also necessary to assess the overall adequacy of the model as an integrated set.

32. Several indices of overall model adequacy (goodness-of-fit) exhibit a satisfactory picture

After the construct is inserted into a larger model with other constructs (be it another measurement model or a structural model), the previous validation steps should be run again and the researcher should additionally assess whether:

33. The integrated measurement model presents an overall satisfactory degree of adequacy

34. Estimated parameter values do not change substantially (in magnitude or significance level) when the construct is inserted into the integrated measurement model

35. Estimated parameter values do not change substantially (in magnitude or significance level) after the transition from the measurement model to the structural model

After a preliminary assessment of the validity of the constructs and their indicators, based on within-construct correlations and further conceptual reasoning, certain constructs were eliminated from the study. The preliminary measurement model was then composed of 13 constructs (three related to export performance) and 56 indicators, which was too large to be estimated with the sample collected. The next step in the purification and simplification of the model consisted of sub-dividing the model into four component parts - with constructs related to export performance, external environment, firm characteristics and strategy. Two constructs (degree of differentiation of export venture's offer and degree of adaptation of product mix) were involved only in contingent relationships, but the sample was not large enough to properly test for moderating effects with latent variables. We decided to keep these two constructs in the model temporarily in order to help with the assessment of the measurement model of the other related constructs. Afterwards, they were removed to perform the final analysis of the model.

The sample was split into two halves: a calibration sub-sample and a validation sub-sample. The assessment framework (Table 3) was then applied to each partial measurement model and some constructs were eliminated either because they did not conform to the desirable psychometric properties or because they were involved only in moderating relationships. From this piecewise analysis, eight integrated measurement models (that is, composed of constructs from all four main groups) were built. These eight competing measurement models had between seven and nine latent variables and between 24 and 26 indicators. These models were further depurated by the application of the procedures of the assessment framework, but this time the whole sample was used. Four integrated measurement models showed reasonable psychometric properties and fit the empirical data and were the basis for four competing structural models. One may question whether the repeated application of the validation framework would not suffer from capitalization on the specific characteristics of a given sample. We believe not. First of all, on each run a different model was tested. Besides, some tests were run on sub-samples and others on the full sample. Furthermore, when the number of changes to the model is small (that is, less than $15 \%$ of the indicators are changed - either added, dropped or moved around latent variables) the same sample used to estimate the measurement model can be used to estimate the structural model (Hair et al., 2005). 


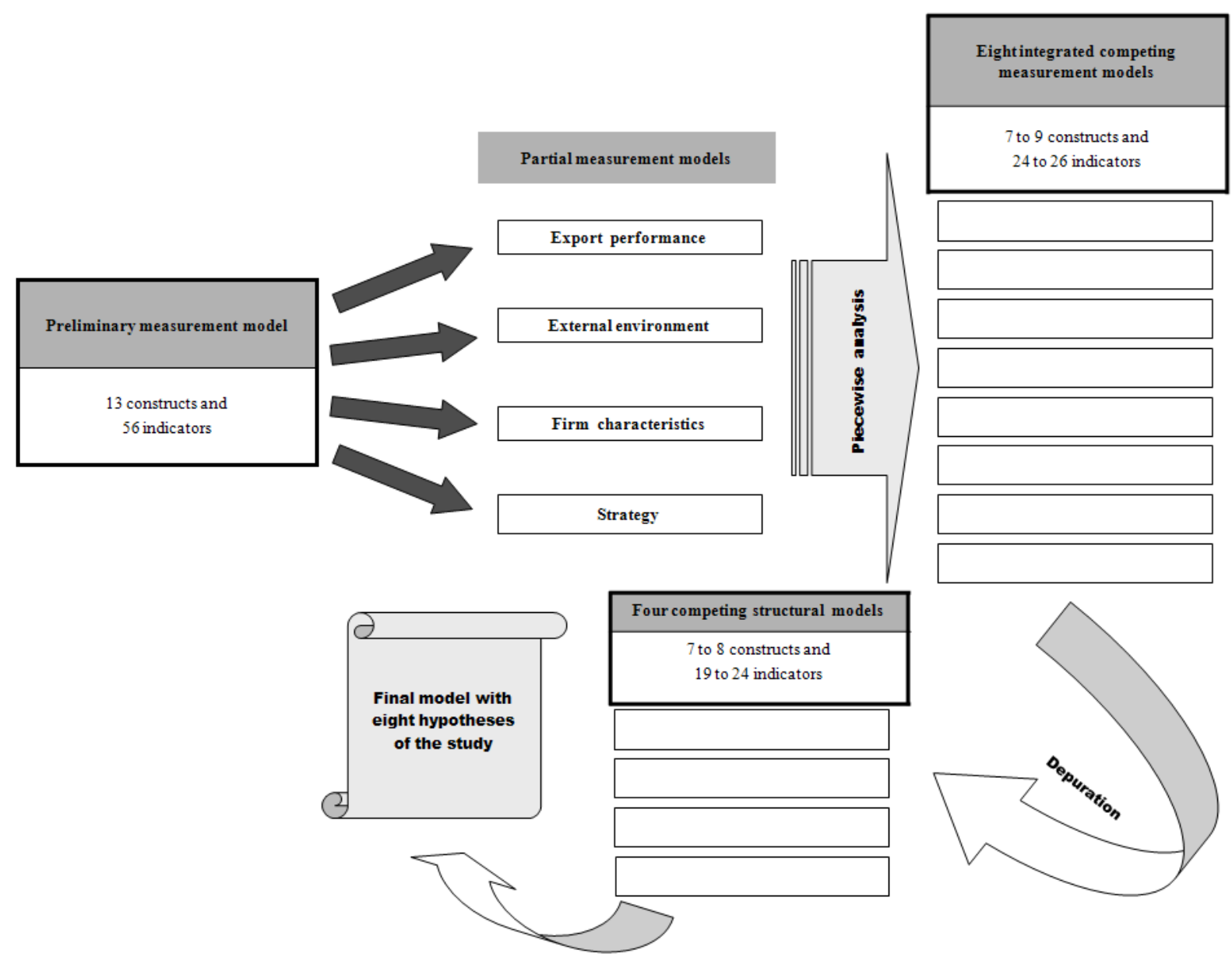

Figure 2. Illustration of the Validation and Comparative Assessment of Competing Models and the Development of the Final Explanatory Model

The four competing structural models contained between seven and eight constructs and between 19 and 24 indicators each. One of them was clearly superior to the others as far as psychometric properties and fit to empirical data are concerned. This is the final explanatory model that was used to test the hypotheses. Figure 2 summarizes the steps in the construction of the final model.

\section{Measures}

We searched the literature for operationalizations of our focal constructs. Whenever we considered previous operationalizations not appropriate, we developed and validated new scales. We chose multiple indicators for each construct since an average of at least three indicators per reflectively-measured construct is recommended to satisfy identification requirements (Hair et al., 2005; Rindskopf \& Rose, 1988). Since the measure purification process led us to remove some indicators, some constructs were locally sub-identified (only two indicators), some were just-identified (exactly three indicators), but the integrated measurement model, as a whole, was identified. Unless otherwise noticed, all indicators were rated in five-point semantic-differential scales.

\section{Dependent variables}

Most researchers have employed rather simplistic operationalizations of export performance, in 
terms of domain coverage and operation representation of the conceptual facets (Carneiro, Rocha, \& Silva, 2007). Nonetheless we have been able to identify seven measurement models of export performance that clearly stand out in terms of content and form: Cavusgil and Zou, 1994; Lages and Lages, 2004; Lages, Lages, and Lages, 2005; Shoham, 1998, 1999; Styles, 1998; and Zou, Taylor, and Osland, 1998. However, all of them have their own limitations and have been criticized elsewhere (Diamantopoulos, 1999; Styles, 1998). We decided to build on them, but also to develop a new measurement model for the export performance construct that would better comply with the generic framework for the characterization of the construct (Table 3).

We identified 116 distinct indicators of the construct, which represented several conceptual facets depicted in Table 1. Before choosing which specific indicators to use, it was necessary to explicitly define the delimitation of the construct. We chose to model only the economic aspects of export performance, leaving out of our model other classes of measures, such as market performance, strategic performance, etc. This economic sub-domain of the construct was initially modeled by three facets: export revenues, export revenue growth, and export profitability (Figure 3). A first-order multidimensional specification was deemed reasonable and, for simplicity, we chose only a reflective perspective between indicators and dimensions.


Figure 3. Economic Frontier of Export Performance Chosen for This Study

Eleven indicators were initially chosen to represent the three economic facets of export performance (Table 4), based on the list of 116 indicators extracted from the literature. Although the number of indicators selected was limited for practical reasons, this procedure reasonably satisfies content validity requirements. 
Table 4

\section{Selected Indicators of (Economic) Export Performance and Their Preliminary Association with Dimensions of the Construct}

\begin{tabular}{|c|c|c|}
\hline Dimension & Abbreviation & Description of the meaning of the indicator \\
\hline \multirow{4}{*}{$\begin{array}{c}\text { Export } \\
\text { revenues }\end{array}$} & SRevPas & Satisfaction with past export venture's revenues \\
\hline & RePasOt & $\begin{array}{l}\text { Export venture's revenues vis-à-vis average revenues of other export ventures } \\
\text { of the firm }\end{array}$ \\
\hline & VPasComp* & $\begin{array}{l}\text { Past export venture's volume vis-à-vis other Brazilian firms exporting to the } \\
\text { same country }\end{array}$ \\
\hline & VFutOt & $\begin{array}{l}\text { Expected future export venture's volume vis-à-vis expected average volume of } \\
\text { other export ventures of the firm }\end{array}$ \\
\hline \multirow{3}{*}{$\begin{array}{l}\text { Export } \\
\text { revenue } \\
\text { growth }\end{array}$} & SGRPas & Satisfaction with past growth of export venture's revenues \\
\hline & GRPasOt & $\begin{array}{l}\text { Past growth of export venture's volume vis-à-vis average volume growth of } \\
\text { other export ventures of the firm }\end{array}$ \\
\hline & GRFutOt & $\begin{array}{l}\text { Expected future growth of export venture's volume vis-à-vis expected average } \\
\text { volume growth of other export ventures of the firm }\end{array}$ \\
\hline \multirow{4}{*}{$\begin{array}{l}\text { Export } \\
\text { profitability }\end{array}$} & SProPas & Satisfaction with export venture's past profit margin \\
\hline & PrPasOt & $\begin{array}{l}\text { Past export venture's profitability vis-à-vis average profitability of other export } \\
\text { ventures of the firm }\end{array}$ \\
\hline & ProfFut & Expected future export venture's profitability \\
\hline & PrFutOt & $\begin{array}{l}\text { Expected future export venture's profitability vis-à-vis expected average } \\
\text { profitability of other export ventures of the firm }\end{array}$ \\
\hline
\end{tabular}

Note. *This indicator was dropped due to high incidence of missing data. All indicators were rated on five-point semantic differential scales with anchor words such as very dissatisfied, very satisfied or much less, much more or similar ones. The temporal bracket explicitly stated in the questions was last three years or next three years.

The purification process indicated that indicators of past performance seemed to tell a different story than indicators of future performance. Moreover, export revenues and export revenue growth did not seem to be distinct dimensions and were merged. So, in the final model, the export performance construct was modeled as a two-dimensional construct composed only of past indicators of (a) export venture's revenues and their growth, and (b) export venture's profitability. The fact is that the broad conceptual model depicted in Table1, although important for the necessary decisions about the conceptual frontiers of the construct that may be relevant to a given particular study, may meet practical limitations in empirical research. In this particular study the high correlation of export revenues and of export revenue growth indicates that these two aspects of the construct may be so intertwined that it may be difficult in empirical practice to independently assess the impacts of the determinants on each of them.

\section{Independent variables}

Psychic distance. We initially operationalized psychic distance with five indicators: degree of perceived difference between Brazil and the host country (based on an index collected by Leite, Rocha, \& Figueiredo, 1988), cultural distance (using Hofstede's (1997) cultural dimensions, as suggested by Kogut \& Singh, 1988), and three indicators of differences between business environments of Brazil and the host country (adapted from Evans \& Mavondo, 2002). The purification process showed that these three indicators of the business environment represented a different concept from the other two indicators. Also, psychic distance indicators and indicators of the development level of the host country were very highly correlated in this particular sample, so we decided to use only one of the two constructs in the final model. This construct was still called psychic distance and it 
was composed of the first two indicators (degree of perceived difference between Brazil and the host country, and Hofstede's cultural distance score) and a third indicator (the human development index, HDI, published by the United Nations).

Business distance. This construct actually emerged from the exploratory factor analysis and was confirmed by the confirmatory factor analysis, but finds support in the literature (Evans \& Mavondo, 2002). It was composed of the three indicators covering perceived differences in economic development level, buyers' characteristics, and business practices between Brazil and the host country.

Barriers in the host country. This construct has been operationalized in various ways in the literature (see, for example, Cicic et al., 2002; Madsen, 1989), using financial or legal measures. We initially chose four indicators for the construct - perceptions about import taxes in the host country, legal and bureaucratic obstacles, prejudice against Brazilian products, and preference for local firms. The fourth indicator had many missing values $(23.0 \%)$ and was dropped. The third indicator was removed because it did not show a high enough correlation with the other two. Although the construct was locally sub-identified, we decided not to supplement it with other indicators from secondary sources because we were interested in the particular situation of a given product in a given country and not in general information about host country characteristics or practices.

Status of the exporting activity. Several variables have been used to represent the status and organization of the exporting activity. We chose three indicators: degree of autonomy of export managers, prestige of export managers vis-à-vis other managers, and importance given to exports vis-à-vis other activities (Beamish, Karavis, Goerzen, \& Lane, 1999; Bijmolt \& Zwart, 1994; Cicic et al., 2002; Das, 1994; Drogendijk \& Slangen, 2006; Katsikeas et al., 1996; Madsen, 1989).

Systematization of export planning. Researchers have characterized this construct according to the level of pro-activity towards exports and the degree of systematization or formalization, as well as the level of effort dedicated to the activity (Bijmolt \& Zwart, 1994; Julian, 2003; Madsen, 1989; Moini, 1995; Robinson \& Pearce, 1988; Shoham, 1996, 1999). We initially chose three indicators: degree of formalization of the export planning process, permanent search for export opportunities, and frequency of visits to the foreign market. However, the latter indicator was not well correlated with the other two and was dropped.

\section{Results}

\section{Model assessment}

The model that survived the scrutiny and was fitted to empirical data is shown in Figure 4. The constructs in the final model showed reasonably good psychometric properties (Table 5) and the overall fit of the model was acceptable (Table 6). 




Figure 4. Structural Model

All standardized loadings were statistically significant and most squared multiple correlations were above .50 , meaning that the respective construct explains more than $50 \%$ of the variance of the respective indicator. Also, except for one construct, average variance extracted is above or just marginally below .50. Given the complexity of the model and this particular sample size, Hair, Black, Babin and Anderson (2005) recommend the following targets for the fit indices: CFI and TLI higher than .92, and RMSEA below .07. Also, GFI greater than .90 is usually considered good fit. Fit indices are near, but not at the desired levels, meaning the model fits the data just reasonably well. In the transition from the measurement model into the structural model, the expected decrease in fit indices was small, suggesting adequacy of the model, but there was an increase in the normed $\chi^{2}\left(\chi^{2} / d f\right)$, meaning that the increase in the degrees of freedom was more than offset by a loss in fit.

Table 5

\section{Associations between Indicators and Constructs}

\begin{tabular}{|c|c|c|c|c|c|}
\hline & $\begin{array}{l}\text { standardized } \\
\text { loading }\end{array}$ & $\begin{array}{l}\text { squared } \\
\text { multiple } \\
\text { correlation }\end{array}$ & $\begin{array}{l}\text { critical } \\
\text { coefficient }\end{array}$ & $\begin{array}{l}\text { composite } \\
\text { reliability }\end{array}$ & $\begin{array}{l}\text { average } \\
\text { variance } \\
\text { extracted }\end{array}$ \\
\hline Export revenues (and their growth) & & & & .84 & .47 \\
\hline $\begin{array}{l}\text { Satisfaction with past export venture's past } \\
\text { revenues }\end{array}$ & .714 & .51 & n.a. & & \\
\hline $\begin{array}{l}\text { Export venture's past revenues vis-à-vis average } \\
\text { revenues of other export ventures of the firm }\end{array}$ & .535 & .29 & $10.541 *$ & & \\
\hline $\begin{array}{l}\text { Satisfaction with past growth of export venture's } \\
\text { revenues }\end{array}$ & .770 & .59 & $18,498 *$ & & \\
\hline $\begin{array}{l}\text { Past growth of export venture's volume vis-à-vis } \\
\text { average volume growth of other export ventures } \\
\text { of the firm }\end{array}$ & .694 & .48 & $12,334 *$ & & \\
\hline
\end{tabular}


Table 5 (continued)

\begin{tabular}{|c|c|c|c|c|c|}
\hline & $\begin{array}{l}\text { standardized } \\
\text { loading }\end{array}$ & $\begin{array}{l}\text { squared } \\
\text { multiple } \\
\text { correlation }\end{array}$ & $\begin{array}{l}\text { critical } \\
\text { coefficient }\end{array}$ & $\begin{array}{l}\text { composite } \\
\text { reliability }\end{array}$ & $\begin{array}{l}\text { average } \\
\text { variance } \\
\text { extracted }\end{array}$ \\
\hline Export profitability & & & & .71 & .49 \\
\hline $\begin{array}{l}\text { Satisfaction with export venture's past profit } \\
\text { margin }\end{array}$ & .834 & .70 & n.a. & & \\
\hline $\begin{array}{l}\text { Past export venture's profitability vis-à-vis } \\
\text { average profitability of other export ventures of } \\
\text { the firm }\end{array}$ & .528 & .28 & $7,991^{*}$ & & \\
\hline Psychic distance & & & & .87 & .71 \\
\hline Human development index (HDI) & .711 & .51 & $32,158 *$ & & \\
\hline $\begin{array}{l}\text { Perceived difference (between Brazil and the } \\
\text { host country) }\end{array}$ & .830 & .69 & $31,186^{*}$ & & \\
\hline Cultural difference score & .968 & .94 & $42,565^{*}$ & & \\
\hline Business distance & & & & .84 & .73 \\
\hline $\begin{array}{l}\text { Differences in the level of economic } \\
\text { development }\end{array}$ & .761 & .58 & $24,052 *$ & & \\
\hline Differences in buyers' characteristics & .907 & .82 & $28,297 *$ & & \\
\hline Differences in business practices & .881 & .78 & $26,786^{*}$ & & \\
\hline Barriers in the host country & & & & .73 & .65 \\
\hline Taxes & .804 & .65 & $17,914^{*}$ & & \\
\hline Legal and bureaucratic obstacles & .810 & .66 & $17,072 *$ & & \\
\hline Status of the exporting activity & & & & .81 & .49 \\
\hline Degree of autonomy of export managers & .553 & .31 & $13,976^{*}$ & & \\
\hline $\begin{array}{l}\text { Prestige of export managers } v i s-\grave{a} \text {-vis other } \\
\text { managers }\end{array}$ & .693 & .48 & $16,575^{*}$ & & \\
\hline $\begin{array}{l}\text { Importance of export activities vis-à-vis other } \\
\text { activities }\end{array}$ & .817 & .67 & $22,012 *$ & & \\
\hline Systematization of export planning & & & & .56 & .36 \\
\hline $\begin{array}{l}\text { Degree of formalization of the export planning } \\
\text { process }\end{array}$ & .733 & .54 & $18,935^{*}$ & & \\
\hline Permanent search for export opportunities & .426 & .18 & $10.312 *$ & & \\
\hline
\end{tabular}

Note. n.a. $=$ not applicable because the unstandardized value of the parameter was fixed at 1.0 in order to provide a measurement scale for the latent variable.

$* p<0,001$

Table 6

\section{Goodness-of-fit indices}

\begin{tabular}{lcccccc}
\cline { 2 - 7 } & \multicolumn{2}{c}{ absolute } & \multicolumn{2}{c}{ relative } \\
\cline { 2 - 7 } & $\chi^{2}$ & $\chi^{2} / d f$ & GFI & RMSEA ** & TLI & CFI \\
\hline Structural model & $519,3 *$ & 3,9 & 0,946 & $0,086(0,078 ; 0,094)$ & 0,873 & 0,901 \\
Measurement model & $470,3 *$ & 3,2 & 0,957 & $0,074(0,066 ; 0,081)$ & 0,907 & 0,927 \\
\hline
\end{tabular}

Note. $* p<.001 ; * *$ Confidence interval shown in parentheses 


\section{Structural nature of the export performance construct}

In the piecewise analysis we fitted seven measurement models of the export performance construct to empirical data:

- Model \# P1: three factors as suggested by the initial conceptual discussion, that is, export revenues (past and future, absolute and relative), export revenue growth (past and future, absolute and relative), and export profitability (past and future, absolute and relative), composed of, respectively: three, three and four indicators;

- Model \# P2: three factors as suggested by the exploratory factor analysis, that is, satisfaction with past absolute export performance, past relative export performance, and future (absolute and relative) export performance, composed of, respectively: three, three and four indicators;

- Model \# P3: two factors, one concerning export revenues and their growth thereof (past and future, absolute and relative), and another concerning export profitability (past and future, absolute and relative), composed of six and four indicators, respectively;

- Model \# P4: one single factor (export performance) incorporating all ten indicators;

- Model \# P5: three factors involving only past indicators, that is, past export revenues (absolute and relative), past export revenue growth (absolute and relative), and past export profitability (absolute and relative), each composed of two indicators;

- Model \# P6: two factors involving only past indicators, that is, past export revenues (absolute and relative) and their growth thereof, and past export profitability (absolute and relative), composed respectively of four and two indicators; and

- Model \# P7: one single factor composed only of past indicators (six in total).

All models were grounded in substantive arguments, except for model \# P2, which emerged from the exploratory analysis. Empirical verification together with substantive reasoning suggested that export performance might be a two-dimensional construct, but the evidence was not conclusive. After extensive tests we chose to model two dimensions: past export revenues (absolute and relative) and their growth, and past export profitability (absolute and relative). We decided to drop indicators of future performance because most correlations between any two past indicators were greater than those between a past and a future indicator. Considering that at the time of the survey Brazilian exporters expected the Brazilian currency to be substantially devalued against the dollar, it is possible that it might have affected expectations of future vis-à-vis past performance.

It should be noted that the model-implied correlation between the two dimensions of export performance is very high (.89) and its square is higher than the average variance explained of each dimension (respectively, .54 and .57), indicating that export revenues and export profitability may not represent distinct aspects of the construct (at least in this particular sample and as operationalized in this study). However, the clearly distinct content of the indicators and the distinct effects that were hypothesized for export revenues vs. export profitability recommended that the two dimensions be kept distinct in the explanatory model.

\section{Effects of explanatory variables}

Five hypotheses were supported (Table 7). The model explained $76.6 \%$ of the observed variance of past export revenues and their growth and $40.1 \%$ of the observed variance of past export profitability. 
Table 7

Impact of Explanatory Variables on Export Performance

Dependent variable

\begin{tabular}{|c|c|c|}
\hline Explanatory variable & $\begin{array}{l}\text { Export revenues (and their } \\
\text { growth) }\end{array}$ & Export profitability \\
\hline Psychic distance & $\mathrm{H}_{1 \mathrm{a}}: \mathrm{NS}^{*}$ & $\mathrm{H}_{1 \mathrm{~b}}:-.134(p=.041)$ \\
\hline Business distance & $\mathrm{H}_{2 \mathrm{a}}: \mathrm{NS}^{*}$ & $\mathrm{H}_{2 \mathrm{~b}}: \mathrm{NS}^{*}$ \\
\hline Barriers in the host country & $\mathrm{H}_{3 \mathrm{a}}:-. \mathbf{5 0 3}(p<.001)$ & $\mathrm{H}_{3 \mathrm{~b}}:-.139(p=.011)$ \\
\hline Status of the exporting activity & $\mathrm{H}_{4}:+\mathbf{. 6 8 5}(p<.001)$ & \\
\hline Systematization of export planning & & $\mathrm{H}_{5}:+.661(p<.001)$ \\
\hline Squared multiple correlation & $76.6 \%$ & $40.1 \%$ \\
\hline
\end{tabular}

Note. The standardized regression coefficient is shown in boldface type.

${ }^{*} \mathrm{NS}=$ non-significant at the $5 \%$ level.

Effects of psychic distance. The construct of psychic distance has received considerable attention in the internationalization literature, but seldom has its impact on export performance been explicitly investigated and results are somewhat mixed. In the present study, we found a moderated negative effect of psychic distance on export profitability, but no significant association with export revenues. In order to understand the effects on profitability, one has to consider revenues and costs. Some costs tend to be smaller in developed countries (e.g., those related to transportation and legal issues), while others tend to be higher (e.g., those related to advertising and promotion). A possible explanation to this non-significant effect on revenues is that, in this particular sample, psychic distance was highly correlated with level of development of the host country, especially after we removed 25 outliers, which, coincidentally, involved ventures in less developed countries that were also psychically distant from Brazil. In more developed countries, higher purchasing power tends to lead to higher revenues (volumes and prices); on the other hand, more competitors and higher rivalry are also expected, putting pressure on volumes and prices. So, there may be opposite influences taking place, which could explain the non-significant effect found for export revenues.

Effects of business distance. We expected a negative relationship, but no significant effects were found. A possible explanation is that managers might pay closer attention to operations in psychically distant markets, in order to cope with the expected higher difficulties - this could offset the expected negative direct impact. Also, since respondents were already doing business in these markets, business distance might have been already reduced.

Effects of barriers in the host country. As expected, negative effects were found. The fact that the effect on export revenues was stronger than that on export profitability can be explained. It is possible that managers would tend to avoid exporting to countries where they perceive higher barriers, thereby decreasing revenues. However, if they decided to export, they might take actions to diminish the expected pressure on profitability.

Effects of status of the exporting activity. A strong positive relationship was found with export revenues. However, there was very high correlation and little discriminant validity between status of exporting activity and systematization of export planning, so results should be interpreted with care. A possible bi-directional relationship may exist between status of the exporting activity and export performance variables, including revenues, as discussed. Besides this feedback effect, status of the exporting activity may play a mediating role with temporal lag between export profitability and export revenues: some increase in export profitability may lead to higher status of exports, which may lead to more support and resources to exports and, therefore, higher revenues. 
Effects of systematization of export planning. The effects of planning over performance have been mixed in the literature. We found a strong positive association, but independent effects should be interpreted with care, given the very high correlation (.94) between systematization of export planning and status of the exporting activity in this particular sample. This correlation seems to indicate that, among Brazilian exporters, those that give more autonomy and importance to exports are also those that plan more carefully. It should also be noticed that a possible feedback effect (as suggested by Bilmolt \& Zwart, 1994), not controlled in this study, may exist. The effect of systematization of export planning was much stronger than that of psychic distance or barriers in the host country. This may be particular to Brazil, as compared to more developed countries, since there is anecdotal evidence that systematization of export planning is still not as common among Brazilian exporters, strengthening the impact of the explanatory variable. It is also possible that the effects of systematization of export planning may be more relevant in intermediate stages of the export development cycle in comparison with initial stages. In the sample collected, $40 \%$ of the firms were in the intermediate stage (export revenues representing between $21 \%$ and $80 \%$ of total revenues).

\section{Conclusion}

As anticipated, export performance exhibited a multidimensional structure, confirming the complex nature of the construct as suggested by Cavusgil and Zou (1994), Katsikeas et al. (2000), Lages and Lages (2004), Lages et al. (2005), Leonidou et al. (2002), Matthyssens and Pauwels (1996), Shoham (1998, 1999), Styles (1998), and Zou et al. (1998). However, the conceptual configuration and the hierarchical structure of its dimensions could not be unequivocally established and should, therefore, merit further investigation in future studies.

The explanatory model with variables from three main areas of influence - external environment, firm characteristics and strategy - was fit to a sample of 389 Brazilian exporters of manufactured products. As a whole, the model explained $76.6 \%$ of the variance of export revenues and $40.1 \%$ of the variance of export profitability. However, given the multi-collinearity between the two dimensions of export performance and between two explanatory variables (status of the exporting activity and systematization of export planning), and also the high correlations between indicators of psychic distance and indicators of development level of the host country, individual effects should be interpreted with care. Export revenues showed a strong positive association with status of the exporting activity and a strong negative association with barriers in the host country. Export profitability showed a strong positive association with systematization of export planning and a moderate negative association with psychic distance and with barriers in the host country. Contrary to expectations, business distance did not show any significant effects on export revenues or profitability.

This study has some limitations. First of all, although there are several indications of adequacy of the overall model and of its components, there is also need for caution. From a methods standpoint, there is a possible bias of collecting information retrospectively and prospectively, and a possible survivor bias. Also, export ventures with the U.S. as a destination country and also export ventures of relative success (vis-à-vis other export ventures of the firm) seem to be over-represented in the sample collected. Although the model incorporated constructs from the three broad areas of influence, firm characteristics and strategy were sub-represented (one construct each), while external environment had three constructs. Possibly some of the relationships are moderated or mediated, but such effects were not controlled in this study.

This study brought conceptual and methodological contributions. Besides integrating contributions from Strategic Management and International Business, we proposed a reasonably balanced model that incorporated variables from three main areas of influence: the external environment, firm characteristics, and strategy. We have also provided further evidence on the multidimensional nature of the export performance construct and have put together a rather comprehensive set of procedures for the validation of multifaceted constructs, which is generic enough 
to be applied in other areas of study. The application of SEM in studies of export performance is not new, although not commonplace either, but the competing models approach used here should be encouraged in future research. This study has also confirmed some results found in the literature, while the developing country setting contributed to the external generalizability of past findings. Practitioners may reap some benefits from the normative orientation that can be drawn from the results.

Future research should continue the quest for a better measure of export performance and the systematic replication of some agreed-upon measuring instrument should allow easier comparison between the results of different studies. Also, the effects of explanatory factors on other facets of export performance (e.g., market performance, strategic performance) should be investigated. Contingencial models and mediating effects should also be evaluated.

\section{Received 20 May 2010; received in revised form 04 March 2011.}

\section{References}

Aaby, N-E., \& Slater, S. (1989). Management influences on export performance: a review of the empirical literature 1978-1988. International Marketing Review, 6(4), 7-25. doi: 10.1108/EUM0000000001516

Arbuckle, J. (2006). Amos 7.0 user's guide. Chicago IL: Amos Development Corporation.

Aulakh, P., Kotabe, M., \& Teegen, H. (2000). Export strategies and performance of firms from emerging economies: evidence from Brazil, Chile, and Mexico. Academy of Management Journal, 43(3), 342-361.

Axinn, C. (1988). Export performance: do managerial perceptions make a difference? International Marketing Review, 5(2), 61-71. doi: 10.1108/eb008353

Axinn, C., Noordewier, T., \& Sinkula, J. (1996). Export strategies and export performance: an empirical investigation of a products/markets typology. In S. Cavusgil (series Ed.), T. Madsen, (Vol. Ed.), Advances in international marketing (Vol. 8, pp. 27-58). Greenwich, CT: JAI Press Inc.

Barney, J. (1996). Gaining and sustaining competitive advantage. Reading, MA: Addison-Wesley Publishing Company.

Beamish, P., Karavis, L., Goerzen, A., \& Lane, C. (1999). The relationship between organizational structure and export performance. Management International Review, 39(1), 37-45.

Bijmolt, T., \& Zwart, P. (1994). The impact of internal factors on the export success of dutch small and medium-sized firms. Journal of Small Business Management, 32(2), 69-82.

Bollen, K., \& Lennox, R. (1991). Conventional wisdom on measurement: a structural equation perspective. Psychological Bulletin, 110(2), 305-314.

Calof, J. (1993). The mode choice and change decision process and its impact on international performance. International Business Review, 2(1), 97-110. doi:10.1016/0969-5931(93)90007-J

Carneiro, J., Rocha, A. da, \& Silva, J. da (2007). A critical analysis of measurement models of export performance. Brazilian Administration Review, 4(2), 1-19, Retrieved from http://www.scielo.br/pdf/bar/v4n2/v4n2a02.pdf. doi: 10.1590/S1807-76922007000200002 
Cavusgil, S., \& Kirpalani, V. (1993). Introducing products into export markets: success factors. Journal of Business Research, 27(1), 1-15. doi:10.1016/0148-2963(93)90012-E

Cavusgil, S., \& Zou, S. (1994). Marketing strategy-performance relationship: an investigation of the empirical link in export market ventures. Journal of Marketing, 58(1), 1-21.

Chetty, S., \& Hamilton, R. (1993). Firm-level determinants of export performance: a meta analysis. International Marketing Review, 10(3), 26-34. doi: 10.1108/02651339310040643

Christensen, C., Rocha, A., \& Gertner, R. (1987). An empirical investigation of the factors influencing export success of Brazilian firms. Journal of International Business Studies, 18(3), 61-77. doi:10.1057/palgrave.jibs.8490412

Cicic, M., Patterson, P., \& Shoham, A. (2002). Antecedents of international performance: a service firms' perspective. European Journal of Marketing, 36(9/10), 1103-1118. doi: $10.1108 / 03090560210437352$

Conant, J., Mokwa, M., \& Varadarajan, P. (1990). Strategic types, distinctive marketing competencies and organizational performance: a multiple measures-based study. Strategic Management Journal, 11(5), 365-383. doi: 10.1002/smj.4250110504

Das, M. (1994). Successful and unsuccessful exporters from developing countries: some preliminary findings. European Journal of Marketing, 28(12), 19-33. doi: 10.1108/03090569410074237

Diamantopoulos, A. (1999). Export performance measurement: reflective versus formative indicators. International Marketing Review, 16(6), 444-457. doi: 10.1108/02651339910300422

Diamantopoulos, A., \& Winklhofer, H. (2001). Index construction with formative indicators: an alternative to scale development. Journal of Marketing Research, 38(2), 269-277. doi: 10.1509/jmkr.38.2.269.18845

Drogendijk, R., \& Slangen, A. (2006). Hofstede, Schwartz, or managerial perceptions? The effects of different cultural distance measures on the establishment mode choices by multinational enterprises. International Business Review, 15(4), 361-380. doi:10.1016/j.ibusrev.2006.05.003

Evans, J., \& Mavondo, F. (2002). Psychic distance and organizational performance: an empirical examination of the international retailing operations. Journal of International Business Studies, 33(3), 515-532. doi:10.1057/palgrave.jibs.8491029

Fiegenbaum, A., Hart, S., \& Schendel, D. (1996). Strategic reference points theory. Strategic Management Journal, 17(3), 219-235. doi: 10.1002/(SICI)1097-0266(199603)17:3<219::AID$\mathrm{SMJ} 806>3.0 . \mathrm{CO} ; 2-\mathrm{N}$

Gomez-Mejia, L. (1988). The role of human resources strategy in export performance: a longitudinal study. Strategic Management Journal, 9(5), 493-505. doi: 10.1002/smj.4250090508

Gupta, A., \& Govindarajan, V. (1982). Business unit strategy, managerial characteristics, and performance. [Working Paper $n^{\circ}$ 21/81]. Graduate School of Management, Boston University, Boston, MA.

Hair, J., Jr, Black, W., Babin, B., \& Anderson, R. (2005). Multivariate data analysis (6th ed.). Upper Saddle River, NJ: Prentice Hall.

Hawawini, G., Subramanian, V., \& Verdin, P. (2003). Is performance driven by industry - or firm-specific factors? A new look at the evidence. Strategic Management Journal, 24(1), 1-16. doi: $10.2307 / 20060508$ 
Hill, C., \& Deeds, D. (1996). The importance of industry structure for the determination of the firm profitability: a neo-austrian perspective. Journal of Management Studies, 33(4), 429-451. doi: 10.1111/j.1467-6486.1996.tb00163.x

Hirschey, M., \& Wichern, D. (1984). Accounting and market-value measures of profitability: consistency, determinants and uses. Journal of Business and Economic Statistics, 2(4), 375-383.

Hofstede, G. (1997). Cultures and organizations: software of the mind. New York: McGraw-Hill.

Holzmüller, H., \& Stöttinger, B. (1996). Structural modeling of success factors in exporting: cross-validation and further development of an export performance model. Journal of International Marketing, 4(2), 29-55.

Itaki, M. (1991). A critical assessment of the eclectic theory of the multinational enterprise. Journal of International Business Studies, 22(3), 445-460. doi:10.1057/palgrave.jibs.8490310

Jacobson, R. (1990). Unobservable effects and business performance. Marketing Science, 9(1), 74-85. doi: $10.1287 / \mathrm{mksc} .9 .1 .74$

Johanson, J. \& Vahlne, J.-E. (1977). The internationalization process of the firm: a model of knowledge and increasing foreign market commitment. Journal of International Business Studies, 8(1), 23-32. doi:10.1057/palgrave.jibs.8490676

Julian, C. C. (2003). Export marketing performance: a study of thailand firms. Journal of Small Business Management, 41(2), 213-221. doi: 10.1111/1540-627X.00077

Katsikeas, C., Leonidou, L., \& Morgan, N. (2000). Firm-level export performance assessment: review, evaluation and development. Academy of Marketing Science, 28(4), 493-511. doi: $10.1177 / 0092070300284003$

Katsikeas, C., Piercy, N., \& Ioannidis, C. (1996). Determinants of export performance in a European context. European Journal of Marketing, 30(6), 6-35. doi: 10.1108/03090569610121656

Knight, G., Madsen, T., \& Servais, P. (2004). An inquiry into born-global firms in Europe and the USA. International Marketing Review, 21(6), 645-665. doi: 10.1108/02651330410568060

Kogut, B. (1985). Designing global strategies: comparative and competitive value-added chains (part 2). Sloan Management Review, 27(Summer), 27-38. doi: 10.1225/SMR001

Kogut, B., \& Singh, H. (1988). The effect of national culture on the choice of entry mode. Journal of International Business Studies, 19(3), 411-432. doi:10.1057/palgrave.jibs.8490394

Lages, L. F., Lages, C., \& Lages, C. R. (2005). Bringing export performance metrics into annual reports: the APEV scale and the perfex scale. Journal of International Marketing, 13(3), 79104.

Lages, L. F., \& Lages, C. R. (2004). The STEP scale: a measure of short-term export performance improvement. Journal of International Marketing, 12(1), 36-56. doi: 10.1509/jimk.12.1.36.25647

Leite, H., Rocha, A. da, \& Figueiredo, K. (1988). A percepção cultural e a decisão de exportar. In A. da Rocha (Org.), Gerência de exportação no Brasil (Cap. 3, pp. 61-71). Rio de Janeiro: UFRJ.

Leonidou, L., Katsikeas, C., \& Samiee, S. (2002). Marketing strategy determinants of export performance: a meta-analysis. Journal of Business Research, 55(1), 51-67. doi: 10.1016/S01482963(00)00133-8

Little, R., \& Rubin, D. (1987). Statistical analysis with missing data. New York: John Wiley \& Sons. 
Madsen, T. (1989). Successful export marketing management: some empirical evidence. International Marketing Review, 6(4), 41-57. doi: 10.1108/EUM0000000001518

Madsen, T. (1998). Managerial judgment of export performance. Journal of International Marketing, $6(3), 82-93$.

March, J., \& Sutton, R. (1997). Organization performance as a dependent variable. Organization Science, 8(6), 698-706. doi: 10.1287/orsc.8.6.698

Matthyssens, P., \& Pauwels, P. (1996). Assessing export performance measurement. In S. T. Cavusgil, \& C. Axinn (Eds.), Advances in international marketing (pp. 85-114.). Greenwich, CT: JAI Press Inc.

McGahan, A., \& Porter, M. (1997). How much does industry matter, really? Strategic Management Journal, 18(S1), 15-30. doi: 10.1002/(SICI)1097-0266(199707)18:1+\%3C15::AIDSMJ916\%3E3.0.CO;2-1

Miller, C., \& Cardinal, L. (1994). Strategic planning and firm performance: a synthesis of more than two decades of research. Academy of Management Journal, 37(6), 1649-1665. doi: $10.2307 / 256804$

Miller, D. (1988). Relating Porter's business strategies to environment and structure: analysis and performance implications. Academy of Management Journal, 31(2), 280-308.

Moini, A. (1995). An inquiry into successful exporting: an empirical investigation using a three-stage model. Journal of Small Business Management, 33(3), 9-25.

O'Grady, S., \& Lane, H. (1996). The psychic distance paradox. Journal of International Business Studies, 27(2), 309-333. doi:10.1057/palgrave.jibs.8490137

Pearce, J., Freeman, E., \& Robinson, R. (1987). The tenuous link between formal strategic planning and financial performance. Academy of Management Review, 12(4), 658-675.

Pearce, J., Robbins, D., \& Robinson, R. (1987). The impact of grand strategy and planning formality on financial performance. Strategic Management Journal, 8(2), 125-134. doi: $10.1002 /$ smj.4250080204

Porter, M. (1980). Competitive strategy: techniques for analyzing industries and competitors. New York: The Free Press.

Porter, M. (1985). Competitive advantage: creating and sustaining competitive performance. New York: The Free Press.

Porter, M. (1990). The competitive advantage of nations, New York: Free Press.

Powell, T. (1992). Organizational alignment as competitive advantage. Strategic Management Journal, 13(2), 119-134. doi: 10.2307/2486409

Reid, S. (1981). The decision-maker and export entry and expansion. Journal of International Business Studies, 12(2), 101-112. doi:10.1057/palgrave.jibs.8490581

Rindskopf, D., \& Rose, T. (1988). Some theory and applications of confirmatory second-order factor analysis. Multivariate Behavioral Research, 23(1), 51-67.doi: 10.1207/s15327906mbr2301_3

Robinson, R., \& Pearce, J. (1988). Planned patterns of strategic behavior and their relationship to business unit performance. Strategic Management Journal, 9(1), 43-60. doi: 10.1002/smj.4250090105

Schendel, D. (1997). Editor's introduction to the 1997 summer special issue: the interaction of 
organizational and competitive influences on strategy and performance. Strategic Management Journal, 18 (S1), 1-3. doi: 10.1002/(SICI)1097-0266(199707)

Shoham, A. (1996). Effectiveness of standardized and adapted television advertising: an international field study approach. Journal of International Consumer Marketing, 9(1), 5-23. doi: 10.1300/J046v09n01_02

Shoham, A. (1998). Export performance: a conceptualization and empirical assessment. Journal of International Marketing, 6(3), 59-81.

Shoham, A. (1999). Bounded rationality, planning, standardization of international strategy, and export performance: a structural model examination. Journal of International Marketing, 7(2), 24-50.

Slater, S., \& Narver, J. (1993). Product-market strategy and performance: an analysis of the Miles and Snow strategy types. European Journal of Marketing, 27(10), 33-51. doi: $10.1108 / 03090569310045870$

Snow, C., \& Hrebiniak, L. (1980). Strategy, distinctive competence and organizational performance. Administrative Science Quarterly, 25(2), 317-336. doi: 10.2307/2392457

Styles, C. A (1998). Cross-cultural examination of export performance. Journal of International Marketing, 6(3), 5-31.

Theodosiou, M., \& Leonidou, L. (2003). Standardization versus adaptations of international marketing strategy: an integrative assessment of the empirical research. International Business Review, 12(2), 141-171. doi:10.1016/S0969-5931(02)00094-X

Venkatraman, N., \& Prescott, J. (1990). Environment-strategy coalignment: an empirical test of its performance implications. Strategic Management Journal, 11(1), 1-23. doi: $10.1002 / \mathrm{smj} .4250110102$

Venkatraman, N., \& Ramanujam, V. (1986). Measurement of business performance in strategy research: a comparison of approaches. Academy of Management Review, 11(4), 801-814. doi: $10.2307 / 258398$

Walters, P., \& Samiee, S. (1990). A model for assessing performance in small U.S. exporting firms. Entrepreneurship Theory and Practice, 15(2), 33-50.

Welch, L., \& Luostarinen, R. (1988). Internationalization: evolution of a concept. Journal of General Management, 14(2), 34-55.

White, R. (1986). Generic business strategies, organizational context and performance: an empirical investigation. Strategic Management Journal, 7(3), 217-231. doi: 10.1002/smj.4250070304

Zou, S., \& Stan, S. (1998). The determinants of export performance: a review of the empirical literature between 1987 and 1997. International Marketing Review, 15(5), 333-356. doi: $10.1108 / 02651339810236290$

Zou, S., Taylor, C. R., \& Osland, G. E. (1998). The EXPERF scale: a cross-national generalized export performance measure. Journal of International Marketing, 6(3), 37-58. 